\title{
Hjernebark og syntaktiske træer
}

\author{
KeN RAMSHØJ CHRISTENSEN \\ Institut for Sprog, Litteratur og Kultur, Aarhus Universitet, Danmark \\ Center for Funktionelt Integrativ Neurovidenskab, Aarhus \\ Universitetshospital, Danmark
}

\begin{abstract}
The syntax of human language is a recursive, generative system. Both of these properties are ubiquitous in the natural world. In fact, sentences, trees, and brains share the property of hierarchical structure (i.e., tree-structure) as a fundamental principle. Aspects of syntax are subject to general constraints on structure which in themselves have no meaning. In contrast, the way we use and manipulate these structures (usually) are meaningful. Another parallel between trees and brains is that they both have bark, in the brain called cortex. I argue that the activation in the "bark" of the brain depends on the nature of the syntactic tree, that is, structural properties of any given sentence. I present results from two neuroimaging studies on sentence comprehension which also provide support for a much more distributed implementation of language in the brain than is usually assumed, especially in neuropsychology textbooks. In particular, comprehension phenomena at the interface between syntax and pragmatics (i.e., between form and function) engage Broca's area (often called the speech area), whereas purely structural differences in syntactic form engage motor and premotor cortex. Language is a complex system of subsystems (or modules) implemented in the brain as distributed and overlapping networks.
\end{abstract}

\section{OM KORTEX, BARK OG TRAEER}

Denne artikel handler om hvad sætningsstruktur er for noget, og om forholdet mellem hvordan den syntaktiske struktur ser ud på den ene side, og aktiviteten i hjernen under sprogprocessering på den anden side. Titlen er et ordspil, en metafor, der dækker over at træer, sætninger og hjerner har en del tilfælles. Træer har bark på grene og stamme, og på visse træsorter, som f.eks. eg, sprækker 
barken, hvilket giver en overflade fuld af furer. Hjernen består hovedsageligt af hvide celler, den hvide hjernemasse, men overfladen af storhjernen er dækket af et tyndt lag af grå hjernemasse, "de små grå". Dette lag af grå hjernemasse kaldes cortex eller kortex, det latinske ord for bark. Ligesom sprækkerne på træets bark er hjernens overflade fuld af folder (hjernevindinger, latinsk gyri) og furer (sulci). Hjernebarken består af neuroner der kort sagt består af en cellekrop (med en cellekerne, soma), en enkel sendeforbindelse (dvs. output, axon) og en skov af modtagerforbindelser (inputs) der på grund af deres udseende med stammer og forgreninger kaldes "dendritter" eller "dendrittræer", fra græsk déndron der betyder "træ".

Syntaktiske repræsentationer af sætninger kaldes også træer, syntaktiske træer, men ulig rigtige træer vender deres grene nedad (men det er naturligvis bare noget man har valgt, en konvention). Disse træer bruges til at beskrive og redegøre for strukturelle forhold mellem sætningers led og mellem ordene inde i leddene. Hvad alle tingene i Figur 1, dvs. sætninger, træer og hjerner, overordnet har tilfælles, er hierarkisk struktur. En yderligere parallel er at både på træer og på hjerner kan barken inddeles i finere lag, noget der er specielt vigtigt for de syntaktiske træer.

Jeg vil skynde mig at gøre det ganske klart at de konceptuelle (endsige de grafiske) ligheder og paralleller mellem strukturen i sætninger, træer og hjerneceller jeg fremhæver her, ikke skal tages som udtryk for en ontologisk sammenhæng. Der er ikke noget umiddelbart og/eller kausalt forhold (og det behøver der heller ikke at være) mellem f.eks. neuron- og syntaktisk struktur. Den ene forårsager ikke den anden. Der er f.eks. ingen overensstemmelse mellem knuder i syntaktiske træer (de grå cirkler i Figur 1) og cellekerner. Det er væsentligt mere sandsynligt at der er et forhold mellem disse knuder og grupper af celler (herunder deres indbyrdes forbindelser af axoner og dendritter) i neurale netværker, men også her er forholdet ikke lineært men langt mere komplekst. 


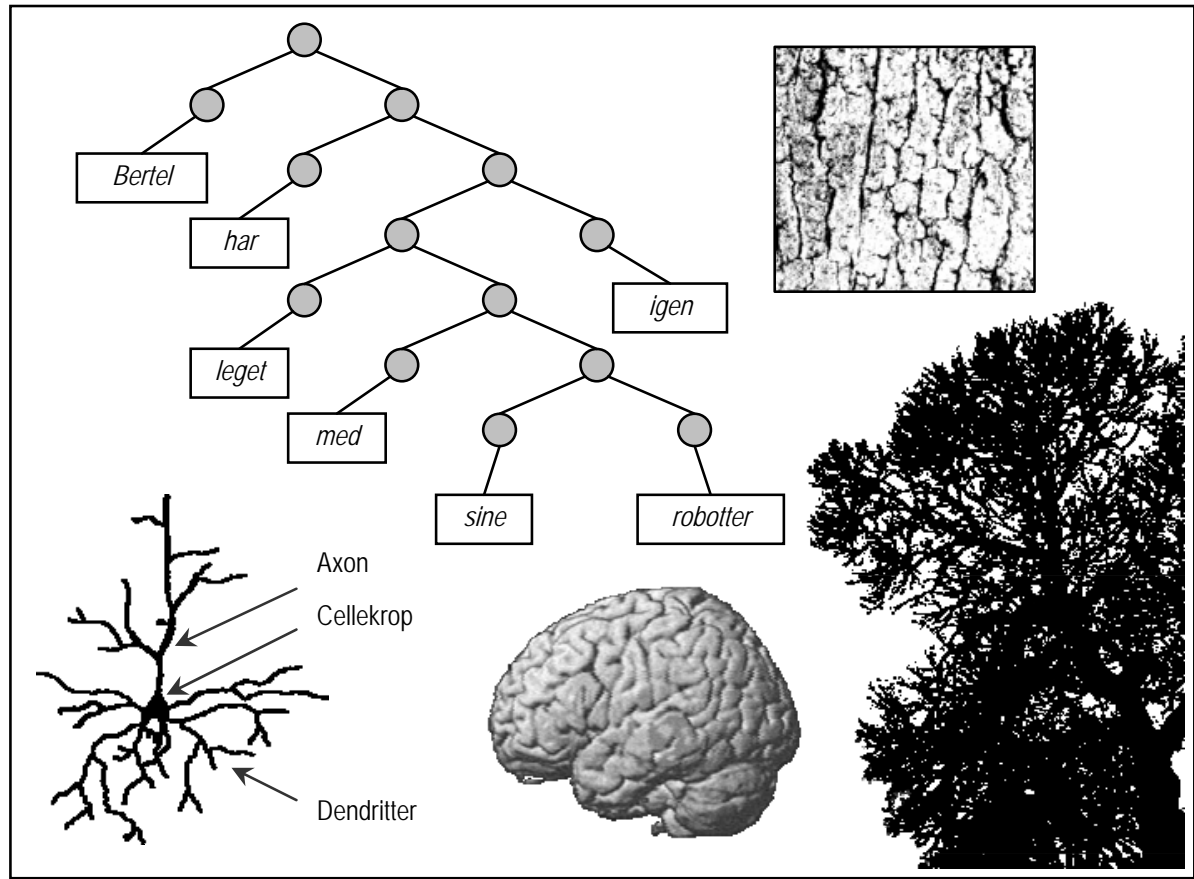

Figur 1. Hierarkiske strukturer i sætninger, hjerner og træer.

Den hierarkiske struktur i sprogets syntaks deler to systemiske træk med planter, buske, blomster og træer, nemlig generativitet og rekursion. Strukturen genereres af et sæt af underliggende regler, ligesom alle mulige skakspil, fortidige og fremtidige, genereres af det samme regelsæt der dikterer hvordan brikkerne kan flyttes. Mængden af de naturlige tal $(1,2,3,4,5,6,7, \ldots)$ er et godt eksempel på et rekursivt system (jf. Leslie et al. 2008). De genereres ud fra formlen $x \rightarrow x+1$, og det rekursive består $\mathrm{i}$ at $x$ optræder på begge sider af pilen; outputtet fra formlen fungerer også som input til samme formel. Både generativitet og rekursion er ganske almindelige og meget udbredte fænomener i naturen. F.eks. kan mange træer, buske og blomsters vækstmønstre beskrives med den rekursive formel der genererer de efterhånden velkendte Fibonacci-strenge $(1,1,2,3,5,8$, $13,21, \ldots)$, se Figur 2. 


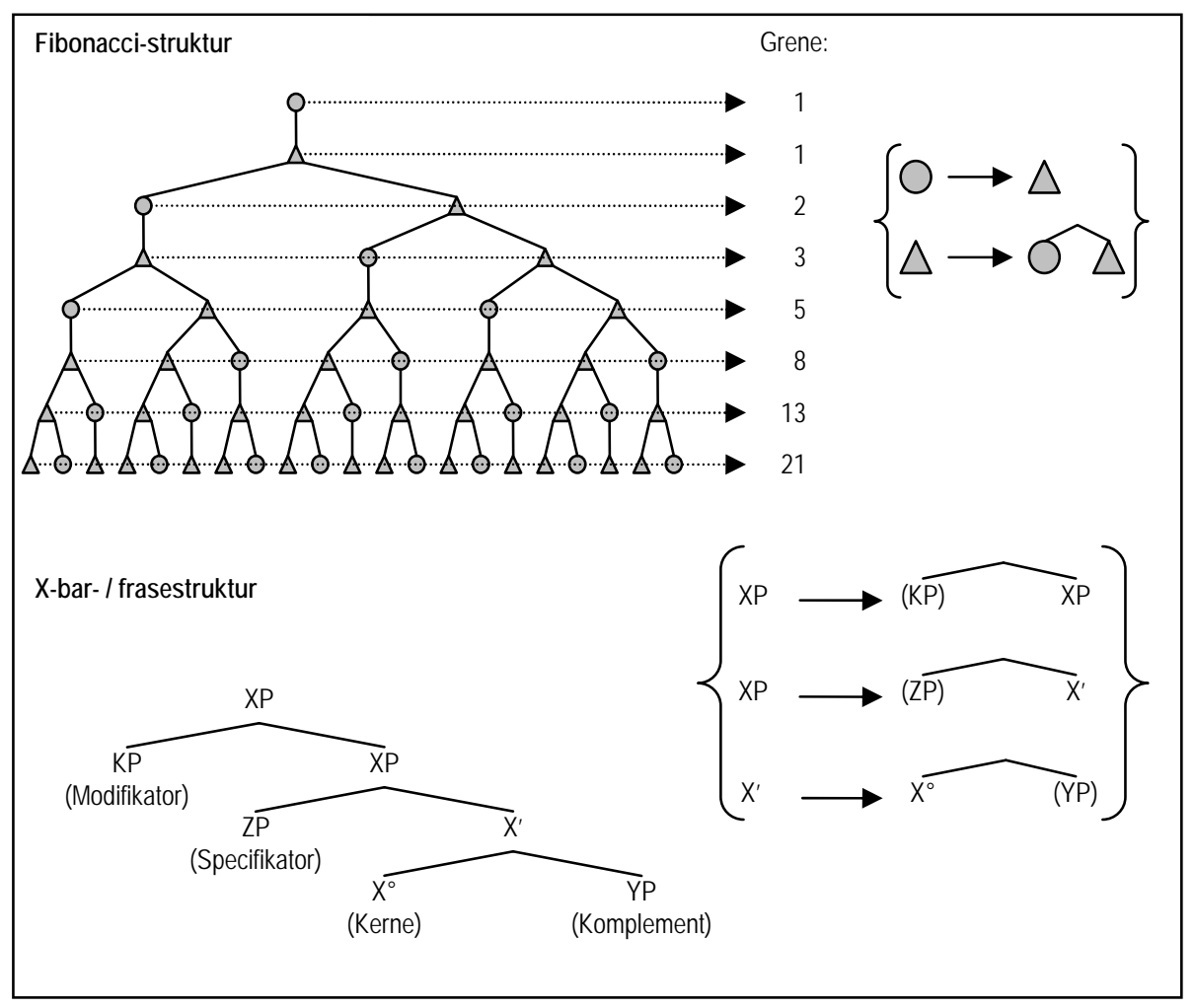

Figur 2. Strukturer genereret med simple rekursive regler. I Fibonacci-strukturen (øverst) har jeg for overskuelighedens skyld anvendt små tre- og firkanter i stedet for de mere traditionelle binære tal i genskrivningsreglerne: $0 \rightarrow 1,1 \rightarrow 0^{\wedge} 1$. Antallet af grene $g$ på et givet niveau $n$, der giver sekvensen $\{1,1,2,3,5,8,13, \ldots\}$, kan også gives med en formel: $g_{n}=g_{n-1}+g_{n-2}$. Fibonacci-sekvenser ligger til grund for et utal af fænomener i naturen, f.eks. forgreningsmønstret hos mange planter og træer og spiralmønstrene som kernerne i solsikkens hoved og skallerne på en ananas eller en grankogle danner. For sammenligningens skyld har jeg indsat genskrivningsregler for den såkaldte "X-bar-struktur", der er den grundliggende struktur i alle ordgrupper og sætninger, $X P \rightarrow(Z P+) X^{\prime}, X^{\prime} \rightarrow X^{\circ}(+Y P)$, selvom sådanne regler ikke er standard $i$ generativ lingvistik. (Både XP, YP, ZP og KP er "XPer", dvs. fraser.) En anden måde at notere strukturen på er at fokusere på det faktum at ordgrupper og sætninger har endocentrisk struktur, dvs. har en kerne. Denne kerne "projicerer" strukturen omkring sig: $\mathrm{X}^{\circ} \rightarrow\left[{ }_{\mathrm{XP}}(\mathrm{ZP})\left[\mathrm{x}^{\prime} \mathrm{X}^{\circ}(\mathrm{YP})\right]\right]$.

Et andet eksempel er fraktalstrukturer såsom snefnug der rekursivt indeholder kopier af dele af sig selv. Sproget har så noget som de andre ikke har. En stor del af Charles Hocketts (1960) berømte design features deler sprog med et eller flere andre kommunikationssystemer i dyreriget, men f.eks. duality of patterning (betydningsløse fonemer kombineres til betydningsfulde morfemer, og morfemer kombineres til ord og sætninger) er unik for sprog (se Crystal 1997: 400-401) og displacement (beskeden handler om noget ikke her og nu) findes 
udover sproget kun i biernes dans. Et andet eksempel er discrete infinity (potentielt uendelig anvendelses af et begrænset system, såsom dansk, f.eks. til at udtrykke tanker og følelser). Som jeg kommer tilbage til nedenfor, er der også andre unikke træk, f.eks. langdistance-dependenser, flytning og negation (nægtelse).

Naturligvis ved træer, buske og blomster ikke at de skal følge de underliggende regler der genererer systemet i deres forgreninger. De har ingen bevidst viden om dem (i og med at de jo ingen bevidsthed har overhovedet). På samme måde har mennesket heller ingen bevidst viden om de regler der genererer konstituenteller frasestrukturen, sætningsstrukturens basale byggesten, som man indenfor den generative formelle lingvistik kalder X-bar-struktur (jf. f.eks. Haegeman 1994, Poole 2002 og Radford 2004), se Figur 2. ${ }^{1}$ Der er således dele af sprogets syntaks der er underlagt generelle fysiske "begrænsninger" eller regelmæssigheder der ikke i sig selv har nogen mening eller betydning formlove, der i den generative grammatik går under betegnelsen "syntaksens autonomi" (The Autonomy of Syntax) og som i resten af videnskaben kaldes The Primacy of Form (Hinzen 2006: 105) (tænk f.eks. bare på hvordan bikubens velkendte mønster af sekskanter opstår som følge af cirkler eller kugler under pres). Måden vi anvender og manipulerer strukturerne på i kommunikation er derimod (som oftest) meningsfuld (se f.eks. Arndt 2003, Togeby 2003). Der er dog ting, også på sætningsniveau, der ikke i sig selv har mening, de er arbitrære, f.eks. det faktum at på de fleste germanske sprog (f.eks. de skandinaviske sprog, tysk, hollandsk og afrikaans) skal det finitte verbum (det der er bøjet for tid) stå på andenpladsen i hovedsætninger umiddelbart efter den første konstituent (som regel subjekt, topik, eller fokus, se nedenfor), mens det ikke er tilfældet i f.eks. moderne fransk og engelsk, japansk, græsk, spansk, tyrkisk, koreansk og mange, mange flere. Et andet eksempel er placeringen af verbet i forhold til objektet; på f.eks. dansk, engelsk og hebræisk står verbet før objektet, mens det på f.eks. tysk og hollandsk er omvendt (i hvert fald for indlejrede sætninger og hovedsætninger med hjælpeverber); se også Vikner (2004) om nødvendigheden af en formel tilgang til sprogvidenskaben.

Den for nuværende vigtigste parallel mellem sætninger, hjerner og træer er dog at sætninger har hierarkisk træstruktur, ligesom rigtige træer, og at hjerner har bark, kortex, ligesom rigtige træer. Det følgende handler om forholdet mellem 
syntaktisk hierarkisk træstruktur og hjernebarken, om hvordan aktiviteten i hjernebarken afhænger af "træsorten", dvs. hvordan den syntaktiske struktur ser ud.

Det er dog bemærkelsesværdigt at sproget har så meget tilfælles med andre biologiske systemer da det ser ud til at være unikt blandt kommunikationssystemer (Chomsky 2005, Deacon 1997, Donald 1991, Hinzen 2006, Pinker 1994, Pinker/Bloom 1990), selvom der som nævnt ovenfor også er fælles træk. Se også Baker (2003) der argumenterer for at sproget er en slags kode der tjener to formål, nemlig på den ene side at skjule information for nogle personer, og på den anden side samtidigt at kommunikere information til andre.

\section{SPROGOMRÅDET OG TALECENTRET}

I begyndelsen af det 19. århundrede fremsatte den tyske neuroanatom Franz Joseph Gall (1758-1828) og hans assistent Johann Gaspar Spurzheim (1776-1832) deres teori kaldet frenologi ifølge hvilken man kunne bestemme folks karakter, tilbøjeligheder, personlige træk og intelligens ved at måle på bulerne på kraniets overflade. Ifølge frenologiens modeller ligger sproget lige under eller bagved øjnene, forældres kærlighed til børn i nakken og destruktiv adfærd bag ørerne ... Frenologien er pseudovidenskabelig, og der findes ikke skyggen af belæg for den, men den kom dog til at spille en vigtig rolle for senere neuropsykologiske forklaringsmodeller, idet den foreslog en, om end forkert, teori om forholdet mellem adfærd og hjerne.

Den mest indflydelsesrige teori om placeringen af sproget i hjernen kan uden tvivl tilskrives den franske kirurg Paul Broca (1824-1880). I 1861 præsenterede Broca sin opdagelse at symptomer på ekspressiv afasi, besværet og "telegrafisk" tale, hang sammen med skade i et bestemt område i den venstre pandelap. Hans opdagelse syntes at pege $\mathrm{i}$ retning af at sproget var en kundskab der var lokaliseret i ét bestemt område, det område der siden har heddet Brocas område (selvom Broca ikke selv drog denne konklusion; han placerede sproget i pandelapperne og anså det for tilfældigt at de skader han så hos sine patienter, var i venstre hjernehalvdel). Kort tid efter, i 1874, viste den tyske neurolog Carl Wernicke (1848-1905) at en hjerneskade i det område der siden har heddet Wernickes område, medførte en skade på sprogforståelsen, impressiv afasi, uden at påvirke talen. 


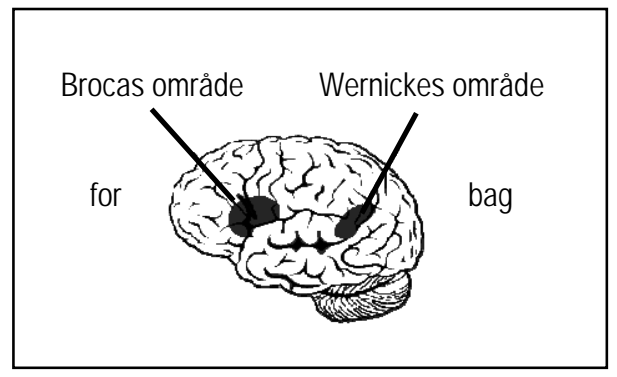

Figur 3. De klassiske sprogområder i venstre hjernehalvdel, Brocas område i pandelappen og Wernickes område bagerst i tindingelappen.

Den ligeledes tyske fysiker Ludwig Lichtheim (1845-1928) fremsatte i 1885 en model for forholdet mellem Brocas og Wernickes områder og forskellige typer afasi, en model der siden har været mere eller mindre standard i medicinske lærebøger. Ifølge Wernicke og Lichtheim var sproget et kompleks af underliggende systemer der havde hver sin plads i hjernen, sprogproduktion (tale) i Brocas område, "talecentret", og sprogforståelsen i Wernickes område. Selv om man i starten af det tyvende århundrede var gået væk fra en sådan proces-relateret tilgang til sprogets placering i hjernen, blev den genoplivet i 1965 af den amerikanske neurolog Norman Geschwind (1926-1984). Modellen lever i bedste velgående i moderne lærebøger i medicin og neuropsykologi til trods for en overvældende mængde af undersøgelser, bl.a. dem i de følgende afsnit, der viser at billedet er meget mere kompliceret end som så, og at der ikke er belæg for at placere lingvistiske eller andre psykologiske aktiviteter i bestemte områder (se f.eks. Grodzinsky 1990: 10-11).

\section{SPROGFORSTÅELSE}

De forsøg jeg omtaler her, handler om sprogforståelse og involverer ingen taleproduktion. Det er vigtigt at understrege da dele af resultaterne viser øget aktivitet i Brocas område som jo mange steder antages at være området for sprogproduktion, "talecentret". Andre dele af resultaterne viser øget aktivitet $i$ motorisk kortex til trods for at der hverken er bevægelse i forbindelse med tale (som sagt er der ingen taleproduktion involveret) eller i forbindelse med selve opgavebesvarelsen i eksperimenterne (fordi de skannerbilleder der tages under selve besvarelsen ikke indgår i analysen). 
Resultaterne af hjerneskanningerne er her alle projiceret på sagittale snit af hjernen, som om hjernen er skåret i skiver fra øre til øre, se Figur 4 (snit nummer 0 er midt mellem hjernehalvdelene, - er mod venstre, og + er mod højre). Forsøgene drejer sig om to forskellige sproglige fænomener, nemlig flytning og noegtelse, der begge er tæt relateret til meget centrale aspekter af menneskets kognition og kommunikation.

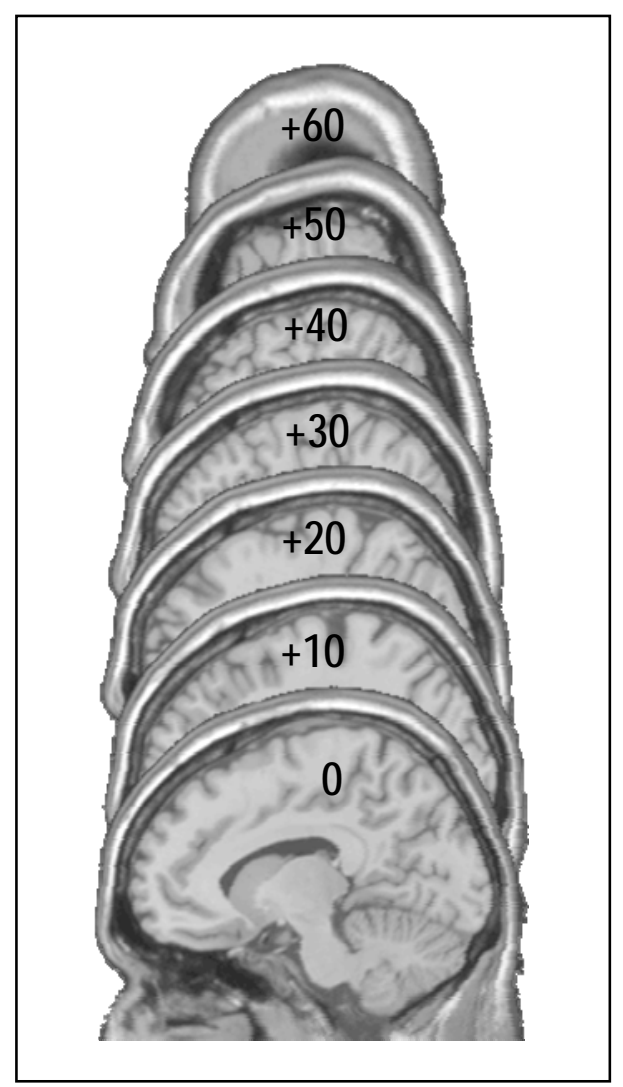

Figur 4. Sagittale skiver. Tværsnit af hjernen fra midten (0), mellem de to hjernehalvdele, og mod højre (+).

Det første forsøg handler om flytning, den syntaktiske proces der muliggør forskellige ordstillinger, dvs. afvigelser fra den umarkerede (og hyppigste ${ }^{2}$ ) Subjekt-Verbum-Objekt; (umarkeret betyder at positionen før det finitte verbum ikke er optaget af et non-subjekt-spørgeord, -topik eller -fokus, sammenlign Jeg kan bare ikke lide urtete, SVO, og Urtete kan jeg bare ikke lide, OSV). Denne proces er unik for sproget og findes ikke i noget andet kommunikationssystem; den nærmeste parallel til flytning er replikation i DNA. Ordet "flytning" er en 
metafor, en teknisk term, og skal ikke forstås bogstaveligt som om ordene fysisk flytter rundt. Det er naturligvis ikke tilfældet. Termen flytning er efterhånden forbundet med så mange misforståelser og overfortolkninger at tiden måske er moden til at skifte den ud; der er da også forskellige empiriske såvel som teoriinterne grunde til at antage at der er tale om "kopiering" snarere end "flytning", jf. The Copy Theory of Movement (se f.eks. Radford 2004: 154-158). Jeg har dog her valgt at bruge den traditionelle term flytning med de fornødne forbehold.

Flytning dækker over det fænomen at et ord kan leve et dobbeltliv hvor det står på én plads (der hvor det udtales) mens dets fulde betydning tilskrives på en anden plads. F.eks. i Billederne har Mille malet er billederne topik og objekt og har den semantiske rolle PATIENS på én gang. At det er topik fremgår af at det står først i sætningen, før det finite verbum og subjektet, mens man kan udlede at det er objekt fordi noget andet er subjekt, nemlig Mille. Men det er først når man har hørt/læst verbet malet at man kan tilskrive billederne den rette semantiske rolle (er billederne blevet set, taget, malet, købt eller solgt?) og dermed tilskrive udsagnet den fulde betydning. Der er således en relation, en langdistancedependens, mellem to strukturelle positioner, og det er disse forhold flytning er en term til beskrivelsen af.

Det næste forsøg handler om noegtelse, eller negation, noget der findes i alle menneskelige kommunikationssystemer, men intetsteds i dyrerigets mangfoldige kommunikationssystemer. Mennesket er således også ene om at kunne tilskrive sandhedsværdier, at lyve, bruge ironi, og at kunne håndtere falske eller modstridende udsagn (Horn 2001).

\section{SYNTAKTISKE HJERNESTUDIER}

Målet med neurosyntaktiske studier er at undersøge strukturens neuroanatomiske korrelater, dvs. hvilke dele af hjernen reagerer på ændringer i den syntaktiske struktur når alle andre faktorer holdes så konstant som muligt. Hypotesen er at syntaksen er implementeret i hjernen i form af et distribueret netværk, og at vigtige syntaktiske distinktioner har neuroanatomiske korrelater. Hvis hypotesen er rigtig, må studier i syntaksens funktionelle neuroanatomi nødvendigvis gøre brug af analyseapparatet fra den teoretiske lingvistik, og måden syntaksen er organiseret på i hjernen, har lingvistisk signifikans (se Grodzinsky 2006) ${ }^{3}$. Målet er således at kortlægge sprogets syntaktotopiske 
distribution, jf. synets retinotopiske og hørelsens tonotopiske distributioner (Mesulam 1998).

Som illustreret i (1) kan negative sætninger på dansk (og en række andre sprog) konstrueres på to måder: enten med et negativt adverbial, f.eks. den prototypiske nægtelse ikke, det negative tidsadverbial aldrig, eller en præpositionsfrase såsom under ingen omstoendigheder, eller med et negativ objekt hvor kernen er en version af ingen (ingenting, intet) med eller uden et forholdsvist kort komplement (ingen penge eller intet nyt men ikke ingen af de helt nye bøger). ${ }^{4}$ Alle disse negative elementer skal stå på samme specielle negationsplads (se Figur 7 nedenfor) for at sætningen er negativ, såvel adverbialer som objekter (jf. Haegemans 1995: 106 Negationskriterium). Flytningen af objektet fra sin umarkerede plads efter verbet til pladsen midt i sætninger har jeg kaldt NEG-shift (Christensen 2003a, 2004, 2005a, 2005b, 2008b).
a. Peter har ikke loest nogen aviser
$i$ dag (, men det har jeg).
b. Peter har ingen aviser loest i dag (, men det har jeg).
a. Har Peter ikke loest
nogen aviser
$i$ dag?
b. Hvilke aviser har Peter ikke loest
$i$ dag?

Som vist i (2) er der også (mindst) to måder at konstruere en spørgende sætning på, der dog modsat de to versioner af negationen i (1) ikke er synonyme: enten som et ja/nej-spørgsmål eller som et $h v$-spørgsmål. I $h v$-spørgsmål står $h v$-ordet først i sætningen (jf. f.eks. at den spørgende version af Han kom kravlende ind $i$ stuen er Hvordan kom han ind i stuen? ikke Han kom hvordan ind i stuen?) ${ }^{5}$, og den flytning som $h v$-frasen (i eksempel (2) hvilke aviser) undergår fra sin umarkerede plads umiddelbart efter hovedverbet til begyndelsen af sætningen kaldes $h v$ flytning (wh-movement).

De to flytninger er forskellige $\mathrm{i}$ og med de har forskellige funktionelle motivationer (negation versus spørgsmål) og forskellige "landingspladser" for flytningerne (midt i sætningen versus først i sætningen), se Figur 5. 


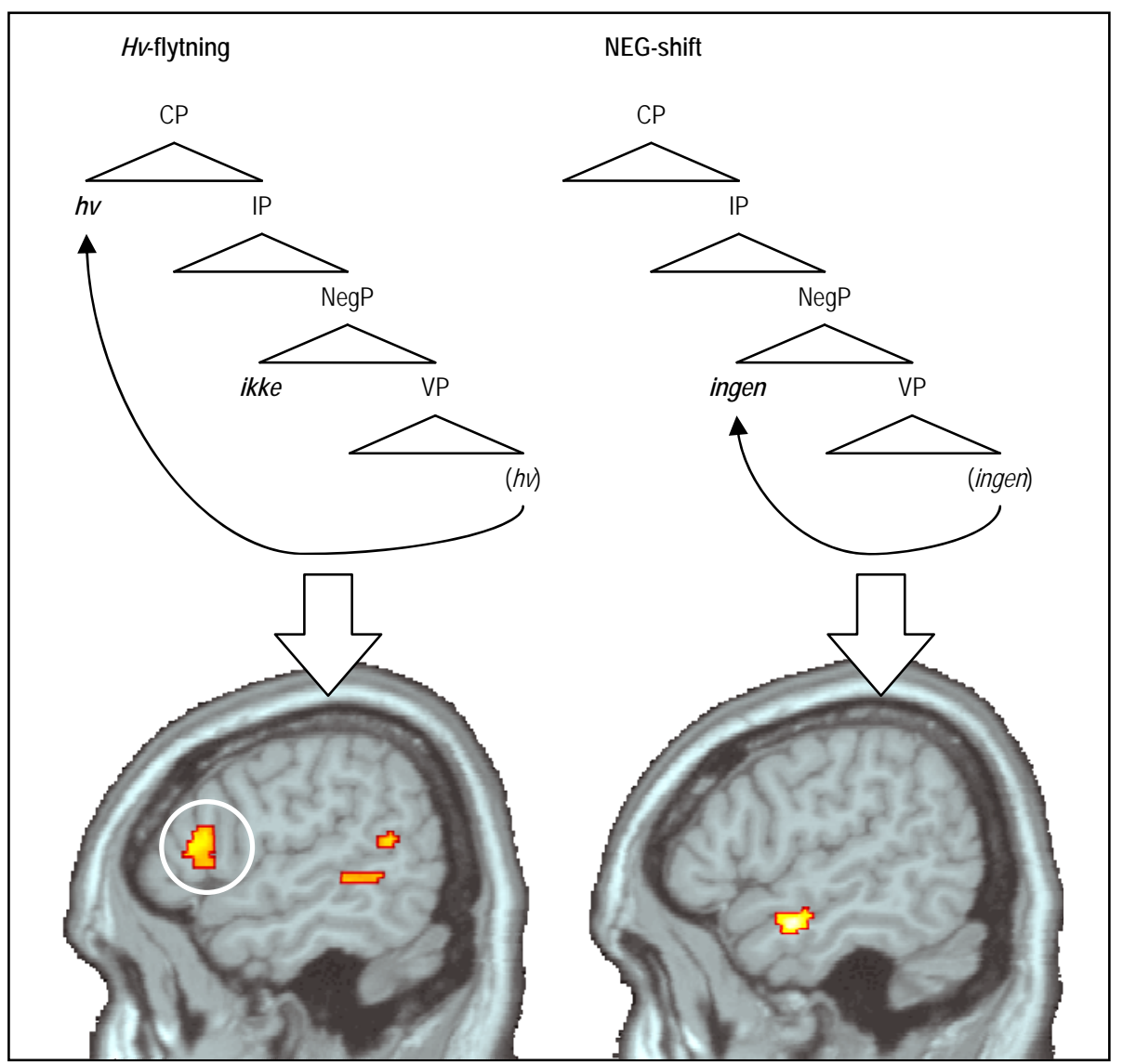

Figur 5. Forskellige flytninger med forskellige neuroanatomiske korrelater. Hv-flytning viser øget aktivitet i den frontale del af Brocas område i venstre pandelap, mens NEGshift viser øget aktivitet i venstre tindingelap.

En hjerneskanningsundersøgelse af tyve personer vha. funktionel magnetisk resonans, forkortet fMRI (functional Magnetic Resonance Imaging), har vist at hjernen reagerer forskelligt på sætninger med og uden sådanne flytninger (Christensen 2005b, 2008a). Ved at trække hjernens aktivitetsmønster når den præsenteres for $j a / n e j$-spørgsmål, fra aktivitetsmønstret den præsenteres for $h v$ spørgsmål, viser resultatet hvor der er mere aktivitet i hjernen ved $h v$-spørgsmål end ved ja/nej-spørgsmål. (FMRI-teknologien måler på blodgennemstrømningen og iltforbruget i hjernen, så med "øget aktivitet" menes der en højere gennemblødning; de farvede pletter på billederne viser hvor hjernen har brugt mere ilt, og altså hvor der er højere gennemstrømning.) Dvs. resultatet af hjerneskanningerne, eller rettere " $h v$ - $>j a / n e j "$-subtraktionen, reflekterer forskellen mellem de to typer sætninger, nemlig den at der er $h v$-flytning i den 
ene, men ikke i den anden, og viser at denne $h v$-flytning øger aktiviteten i Brocas område (Brodmann område 44, 45, men område 46 er også involveret), den hvide cirkel i Figur 5. Det er interessant at bemærke at folk der lider af Brocas afasi, har store problemer med at producere og forstå sætninger med $h v$-flytning (spørgsmål og relativsætninger) og andre flytninger til starten af sætningen (dvs. sætninger med et non-subjekt topik eller fokus, f.eks. Hans kender Grete ikke) (se f.eks. Friedmann 2002, Grodzinsky 2000). Desuden har en række andre skannerforsøg vist en sammenhæng mellem flytning til sætningens venstrekant, "forfeltet", og øget aktivitet i Brocas område (for overblik og sammenlignende analyse, se Christensen 2008a). Ydermere har Angela Friederici og hendes kolleger vist at stigningen i aktivitetsniveau afhænger af antallet af flytninger til "forfeltet" (Friederici et al. 2006). Det har da også været fremsat adskillige gange at Brocas område kunne være det sted i hjernen hvor sådanne flytninger behandles, men der findes også undtagelser, der viser at ikke alle flytninger nødvendigvis giver en effekt i Brocas område. NEG-shift, flytningen af ingen (intet, ingenting) til midt i sætningen, for eksempel, giver ikke øget aktivitet i Brocas område sammenlignet med sætninger uden NEG-shift. I stedet giver det øget aktivitet i venstre tindingelap, se Figur 5. Resultatet af et andet forsøg har vist at dette område reagerer på og synes at foretrække stimuli med rigtig sætningsstruktur frem for ordlister og sætninger med tilfældig ordstilling (Humphries et al. 2005).

At effekten i hjernen af NEG-shift ikke findes i Brocas område stemmer overens med at problemer med negation normalt ikke er en del af symptomerne på afasi (Hagiwara 1995, Lonzi/Luzzatti 1993) ${ }^{6}$. Desuden har en række forsøg som nævnt vist at visse flytninger ikke øger aktiviteten i Brocas område (se Christensen 2008a). Disse resultater er kun problematiske undtagelser hvis man eksempelvis antager at Brocas område tager sig af al flytning (se f.eks. Grodzinsky 2000) eller at den afgørende faktor er arbejdshukommelse (de flyttede ord skal huskes fra man læser eller hører dem, til man kommer til den position hvor de fortolkes, f.eks. når verbet dukker op) (f.eks. Fiebach et al. 2005).

Christensen (2005, 2008a) fremsætter en alternativ teori, Domoenehypotesen, der redegør for alle resultaterne vha. syntaktisk analyse. Ifølge Domoenehypotesen afhænger den øgede aktivitet i hjernen af hvor i det syntaktiske træ ordene flytter hen, hvilket strukturelt domæne (heraf navnet) der er mål for flytningen. (Under 
"kopi"-versionen af flytning, se afsnit 3 ovenfor, er et flyttet element tilstede flere steder i sætningen; den neurale aktivitet målt med fMRI således måske tages som et udslag af de mekanismer der bestemmer hvilken "kopi" der udtales) Som vist i Figur 6 (baseret på Christensen 2005: 30, (22)) kan sætningsstrukturen deles op i tre domæner eller lag, CP (Complementizer Phrase), IP (Inflectional Phrase) og VP (Verb Phrase). Med andre ord sker koblingen mellem struktur og betydning i tre trin (se f.eks. Chomsky 2001, 2005, Diesing 1997, Hinzen 2006, Platzack 2001, Thrane 2004, Uriagereka 1999). CP, IP og VP dækker potentielt over flere XPer (se Figur 2), dvs. har en mere artikuleret struktur end den vist i Figur 6, og udgør således større strukturelle zoner (Rizzi 1997, Belletti 1990, Cinque 1999, Pollock 1989, Chomsky 1995, Larson 1988, Vikner 1989).

I det øverste niveau eller lag, CP-domoenet, tilskrives illokutionær kraft (f.eks. fremsættende vs. spørgende sætninger) og pragmatiske roller (såsom topik eller fokus). Når vi artikulerer visse elementer i begyndelsen af sætningen selvom de tilskrives fuld fortolkning et andet sted, er der således en pragmatisk grund til det. Elementerne spiller en central rolle i forankringen af sætningen i konteksten eller diskursen, hvilket også er grunden til at Platzack (2001) kalder betydningsrepræsentationen af CP for diskursform (Discourse Form). På specifikatorpladsen i CP (spec-CP), dvs. "forfeltet", står hovedsætningens topik eller fokus, f.eks. en diskurspartikel såsom så, et $h v$-spørgeord (hvem, hvad, hvor, etc.), eller et "fremflyttet" subjekt. Kernen i CP, C', er i hovedsætninger udfyldt af det finitte verbum, og i indlejrede sætninger af en konjunktion (complementizer). I mellemlaget, IP-domoenet, findes de grammatiske funktioner og relationer, som f.eks. kongruens mellem det element der er sætningens subjekt (og som således udfylder specifikatorpladsen spec-IP) og det finitte verbum, markering af grammatisk perspektiv, herunder grammatisk tid (tempus: spiser i nutid versus spiste i datid), aspekt (f.eks. kører/kørte vs. har kørt), diatese (aktiv, Jeg ramte den, vs. passiv, Den blev ramt (af mig)), og polaritet (positiv vs. negativ). Når noget artikuleres i IP men fortolkes i VP (dvs. der er flytning fra VP til IP), er det således for at udfylde én af disse grammatiske funktioner, f.eks. rollen som subjekt, snarere end af pragmatiske årsager. Den semantiske repræsentation af IP kalder Platzack (2001) grammatisk form (Grammatical Form). Endelig, på det nederste lag, VP, findes sætningens semantiske eller tematiske kerne, nemlig argumentstrukturen. Det er her de tematiske roller tilskrives, hvem der gjorde hvad mod hvem med hvad, hvor og hvorfor etc., f.eks. Hun (AGENS) 
tegnede en cirkel (PATIENS) på voeggen (STED) med en tusch (INSTRUMENT) for sjov (ÅRSAG).

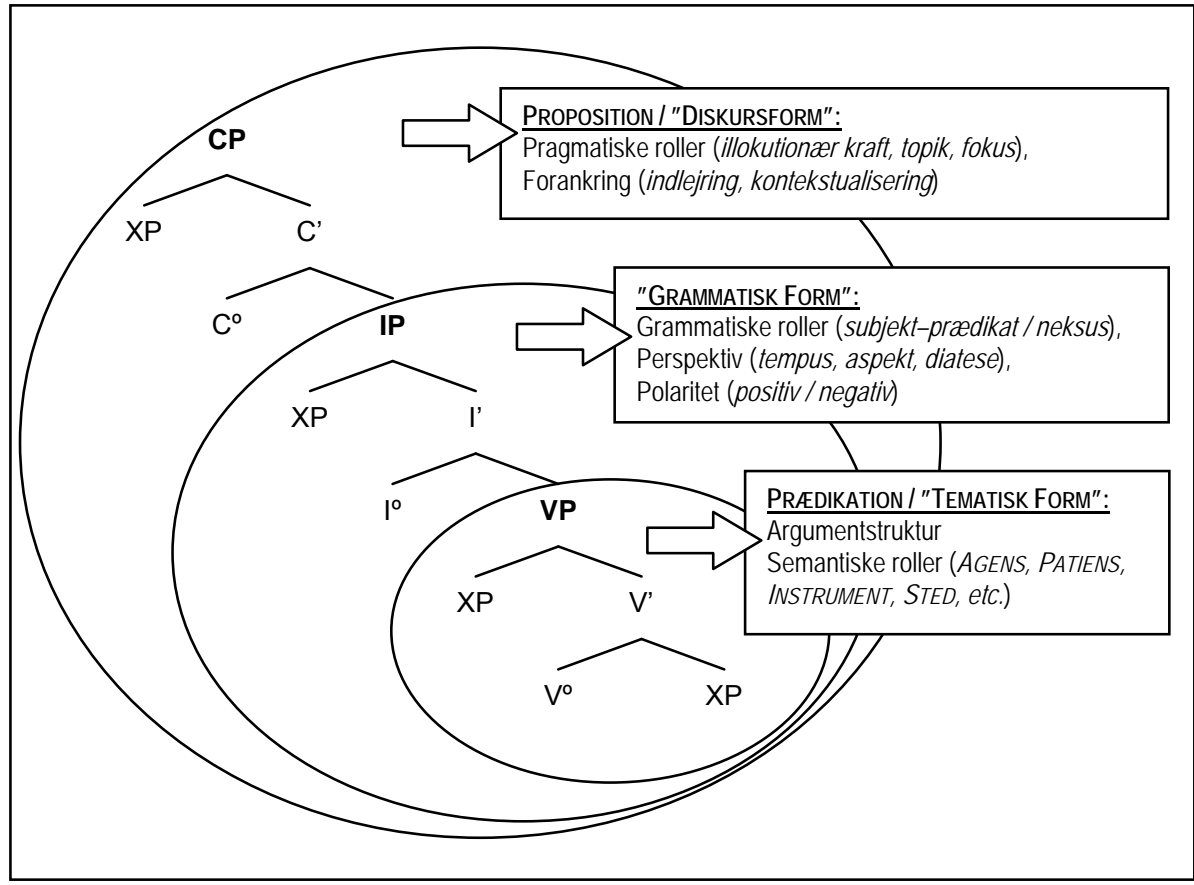

Figur 6. De tre syntaktiske domæner, CP, IP og VP, og deres betydning eller funktion. Det faktum at den samme konstituent $x$ kan være AGENS i VP, Subjekt i IP og Topik eller Fokus i CP, er det der redegøres for med begrebet flytning. Konstituenten $x$ udtales i spec-CP, mens pladserne associeret med rollen som subjekt, spec-IP, rollen som AGENS, spec-VP, er udfyldt af fonologisk "tomme", abstrakte elementer der er forbundet med $x$ i spec-CP. De tre positioner (de tre tilfælde af XP i figuren) indgår $\mathrm{i}$ en såkaldt kæde, hvor $x$ er antecedent og de andre spor, og hvor de tre elementer deler samme reference.

Som nævnt ovenfor er der en speciel plads i strukturen til det element der signalerer sætningsnegation, dvs. en nægtelse i form af et adverbial (f.eks. ikke, aldrig, under ingen omstoendigheder, ingenlunde, på intet tidspunkt) eller et negativt objekt der har undergået NEG-shift (ingen, ingenting, ingen (penge/pakker/grund etc.), intet (nyt/hus/som helst etc.)). Som illustreret i Figur 7 er der således mere struktur i en sætning med negativ polaritet end i en positiv sætning (dertil kommer det åbenlyse at der kræves mindst et ekstra ord for at gøre en sætning negativ end det er tilfældet med positive sætninger). Den del af det syntaktiske træ der huser negationen kaldes NegP (Negation Phrase). 


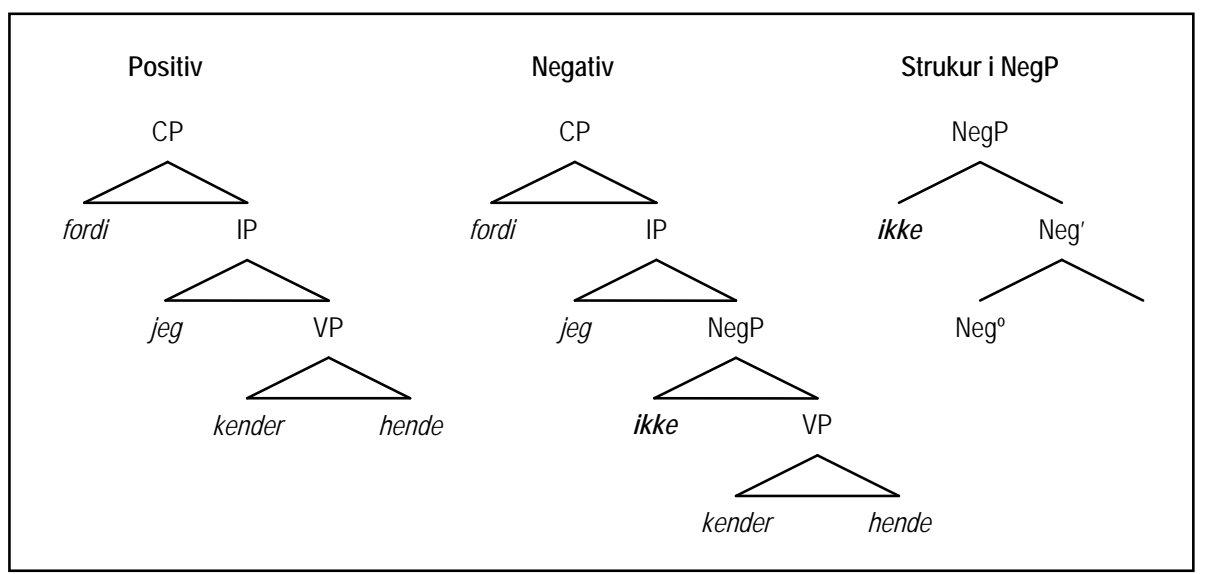

Figur 7. Forskellen i struktur mellem positiv og negativ polaritet. (a) I positive sætninger er der ikke en NegP eftersom der ikke er nogen sætningsnegation. (b) Sætninger med sætningsnegation har en NegP mellem IP og VP. (c) viser den interne struktur i NegP. På dansk er negation et adverbial, f.eks. ikke eller aldrig (til tider et substantiv, såsom ingenting), og i spec-NegP, mens den på andre sprog står i $\mathrm{Neg}^{\circ}$ og enten er et affix (f.eks. oldnordisk) eller et hjælpeverbum (f.eks. finsk). På engelsk kan enten spec-NegP eller $\mathrm{Neg}^{\circ}$ være udfyldt af henholdsvis et adverbial som not eller af suffikset $-n^{\prime} t$ (som i $\left.d o n^{\prime} t\right)$, mens begge pladser kan være fyldt på fransk: pas i spec-NegP og ne i $\mathrm{Neg}^{\circ}$ (ne er dog ved at forsvinde i talesproget).

Sætningsnegation skal ikke forveksles med metalingvistisk negation (f.eks. Ikke om jeg fatter det! eller Ikke at jeg mangler noget) eller konstituentnegation (f.eks. For ikke så loenge siden var jeg i Aalborg). De tre typer har forskellige egenskaber, se (Christensen 2005b: 38-44). Dertil kommer emfatisk eller ekspressiv negation (f.eks. Han er lige blevet klippet, og hvilken frisure har han ikke fået!) der heller ikke er sætningsnegation, men måske snarere en slags metalingvistisk negation. NegP som vist i Figur 7 huser kun sætningsnegation.

NegP udløser det der på engelsk kaldes en island effect, en syntaktisk “ $\varnothing "$. Der er naturligvis igen tale om en metafor; ved flytning er der en forbindelse mellem den artikulerede "kopi" (det "flyttede" element) og "kopien" på pladsen der "flyttes" fra. I generativ grammatik bruges termen C-Command bl.a. til at redegøre for hvordan det lader sig gøre; en syntaktisk " $"$ " kortslutter en sådan forbindelse mellem de to "kopier".

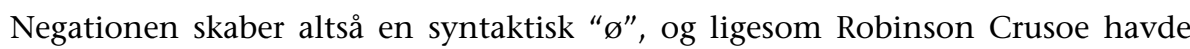
svært ved at slippe væk fra sin øde ø, er det svært eller umuligt for visse typer konstituenter at flytte (flygte) fra syntaktiske "øer", f.eks. når det drejer sig om 
$h v$-flytning af et adverbial henover negationen. Sammenlign f.eks. den positive Hvor loenge vil du bage den pizza __? (muligt svar: 10 minutter) med den negative ${ }^{*}$ Hvor loenge vil du ikke bage den pizza _ ? (den uendelige mængde af mulige svar inkluderer f.eks. 2 sekunder, 45 minutter, 7 dage, 12 år, etc.) (den understregede tomme plads angiver hvor der flyttes fra). Man kunne måske argumentere for at problemet er semantisk, jf. svarmulighederne, men det kan dårligt være tilfældet i følgende eksempler (fra Vikner 1995: 22) Hvad har du inviteret _ for (nogen) studerende? versus *Hvad har du ikke inviteret _ for (nogen) studerende? (sammenlign Hvad for nogen studerende har du (ikke) inviteret _ ?). Desuden udløser negative sætninger to fortolkninger, nemlig den negative og den positive (Jordan 1998), dvs. med og uden en NegP, men efter ca. et sekund er det kun den korrekte, den negative, der overlever (Hasson/Glucksberg 2006); forsøg har også vist at en sætning såsom Døren er ikke åben først repræsenteres mentalt som Døren er åben og først derefter, så sent som halvandet sekund efter den første sætning, som Døren er lukket (Kaup et al. 2006). Det ser således ud til at en negativ sætning er en positiv sætning med noget ekstra på, og dette ekstra noget er en negativ operator og den struktur den "projicerer", NegP. Det er også velkendt at nægtende sætninger er sværere end positive idet de øger reaktionstiden og mængden af de fejl forsøgspersoner laver (Carpenter/Just 1975, Carpenter et al. 1999, Chase/Clark 1972, Hasegawa et al. 2002). Ifølge Christensen (2009) udviser hjernen også såkaldt hviletilstandsaktivitet (Default Mode Activation, se Raichle et al. 2001) ved positiv polaritet (sammenlignet med negativ polaritet) hvilket også indikerer at positiv polaritet er mere basal (standard, umarkeret) end negativ polaritet.

Ved at sammenligne positive og negative sætninger som (3) nedenfor, viser det sig at negationen giver øget aktivitet i et enkelt område i præmotorisk kortex (Brodmanns område 6) (Christensen 2009), se Figur 8 nedenfor. (Samme effekt rapporteres af Hasegawa et al. 2002.) Det præmotoriske område (Brodmanns område 6) regnes normalt ikke som værende blandt "sprogområderne"; det er derimod velkendt at området spiller en vigtig rolle i planlægning og styring af motorisk bevægelse (Joseph 1996: 399, Fuster 2003: 77). Sådanne bevægelser, f.eks. det at gribe ud efter noget, kræver hierarkiske motorprogrammer der ubevist udføres serielt såvel som parallelt. Forsøg har også vist at den præmotoriske hjernebark er involveret i regelstyrede (strukturerede) ikkemotoriske mentale opgaver, nemlig numeriske, sproglige og rumlige opgaver, 
operationer der kræver kognitiv manipulation af elementer eller repræsentationer i arbejdshukommelsen (Hanakawa et al. 2002, Christensen et al. 2007).

(3) a. De sejeste moend kender og bruger også saebe.

b. De sejeste moend kender men bruger ikke saebe.

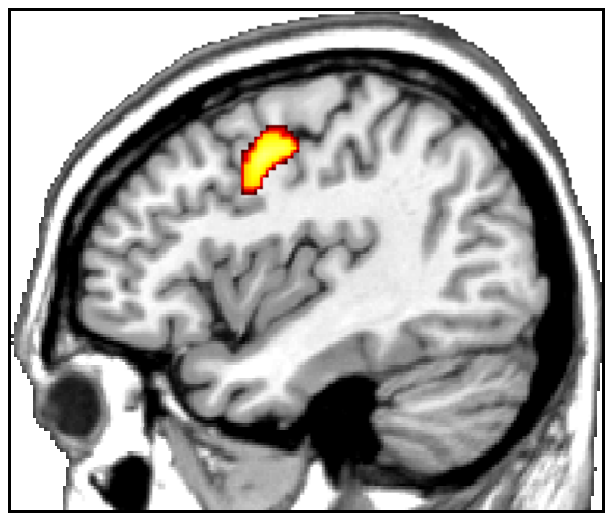

Figur 8. Sætningsnegation øger aktiviteten i et område i venstre præmotorisk kortex (sammenlignet med parallelle eksempler med positiv polaritet).

Der er således en kortikal effekt af den forøgede syntaktiske struktur, en strukturel kompleksitet der ikke er forbundet med flytning (forskellen mellem positiv og negativ i (3) involverer ikke ændringer i ordstillingen), og denne kortikale effekt findes uden for de klassiske sprogområder, Brocas og Wernickes områder. I stedet findes den altså i præmotorisk kortex (se Figur 8).

\section{KONKLUSION}

Sproget er et komplekst system med undersystemer, også kaldet moduler, der er implementeret i hjernen som distribuerede og overlappende netværker. Ét af de centrale undersystemer eller moduler i vores sproglige kompetence er syntaksen der ser ud til at fungere forholdsvist autonomt, og som kan studeres som et selvstændigt system. Paralleller er nemme at finde; af kognitive systemer med modulær opbygning (dvs. systemer med undersystemer) kan man f.eks. nævne vores evne til ansigtsgenkendelse eller vores matematiske "talsans" (evnen til intuitivt at behandle numeriske størrelser og analoge mængder, jf. Butterworth 2000, Dehaene 1997). På samme måde kan f.eks. musklerne og skelettet, åndedrætssystemet og hjertet studeres som mekaniske undersystemer i kroppen, 
og det samme gør sig gældende for centralnervesystemet (dvs. hjernen og rygmarven), eller bare hjernen selv, eller dele af hjernen for den sags skyld. Alt sammen noget der kan studeres som selvstændige undersystemer, selvom de naturligvis ikke fungerer særligt længe uden en levende krop (og vice versa). At syntaksen i hvert fald er et delvist autonomt system kommer f.eks. også til udtryk ved at vi uden videre kan tilskrive sætningsstruktur til en pseudosætning såsom Svilgte krilpoladen snyelsen? til trods for at der ikke er et eneste rigtigt ord tilstede: Det må være et spørgsmål indledt af et finit hovedverbum i datid (pga. endelsen -te, jf. købte, spiste, etc.) efterfulgt af subjekt og objekt, begge i bestemt ental (pga. endelsen -en, jf. pigen, maden).

Selvom syntaksen altså kan ses som et mere eller mindre selvstændigt modul, følger det ikke at den nødvendigvis kan eller bør findes i ét bestemt område i hjernen (jf. også at immunforsvaret, åndedrætssystemet eller centralnervesystemet ikke sidder ét sted i kroppen). Det ville være en neofrenologisk antagelse der ikke findes belæg for. Tværtimod bekræfter hjerneskanningerne det som utallige lingvistiske studier utvetydigt har vist, nemlig at syntaks ikke bare er syntaks, men har en kompleks intern arkitektur med undersystemer der varetager koblingen mellem udtryk og indhold, og mellem lineær/temporal rækkefølge (ord- og ledstilling) og intern hierarkisk struktur (herunder konstituens, skopus og dependens) i sætninger og ordgrupper.

På en konference jeg var til for få år siden, sagde en af foredragsholderne at lingvister har tendens til at postulere for meget struktur. Det er muligvis sandt, muligvis ikke, men uden en velartikuleret syntaktisk teori ville resultaterne overfor blot være en samling af finurlige og højst usandsynlige sammentræf. Det virker mere sandsynligt at siden struktur i høj grad kendetegner vores tankevirksomhed og i særdeleshed vores sprog, så reflekterer aktiviteten i hjernebarken i forsøgene egenskaber i den syntaktiske struktur og de processer der indgår i fortolkningen af den. Med andre ord: Aktiviteten i hjernebarken afhænger af "træsorten", dvs. hvordan den syntaktiske struktur ser ud.

\section{ANERKENDELSER}

Forskningen beskrevet ovenfor var finansieret af Forskningsrådet for Kommunikation og Kultur (FKK), af Danmarks Grundforskningsfonds Center for 
Funktionelt Integrativ Neurovidenskab (CFIN) og af Sproglig Forskerskole Nord,

Aarhus Universitet (SFN). Tak til Sten Vikner for generelle kommentarer.

\section{LITTERATUR}

Arndt, Hans (2003), Sproget. Hverdagens Mirakel, Århus: Aarhus Universitetsforlag.

Baker, Mark C. (2003), "Linguistic Differences and Language Design", Trends in Cognitive Sciences 7.8, pp. 349-353.

Belletti, Adriana (1990), Generalized Verb Movement. Aspects of Verb Syntax, Turin: Rosenberg \& Sellier.

Bresnan, Joan (2001), Lexical Functional Syntax, Oxford: Blackwell.

Butterworth, Brian (2000), The Mathematical Brain, London: Macmillan.

Carpenter, Patricia A., Marcel Adam Just (1975), "Sentence Comprehension: A Psycholinguistic Processing Model of Verification", Psychological Review 82, pp. $45-73$.

Carpenter, Patricia A., Marcel Adam Just, Timothy A. Keller, William F. Eddy, Keith R. Thulborn (1999), "Time Course of fMRI-Activation in Language and Spatial Networks During Sentence Comprehension", NeuroImage 10, pp. 216224.

Chase, William G., H. H. Clark (1972), "Mental Operations in the Comparison of Sentences and Pictures", i: Gregg, L. (ed.), Cognition in Learning and Memory, New York: Wiley.

Chomsky, Noam (1995), The Minimalist Program, Cambridge, Mass.: MIT Press.

Chomsky, Noam (2001) "Derivation by Phase", i: Kenstowicz, Michael (ed.), Ken Hale. A Life in Language, Cambridge, Mass.: MIT Press, pp. 1-52.

Chomsky, Noam (2005), "Three Factors in Language Design", Linguistic Inquiry, 36.1, pp. 1-22.

Christensen, Ken Ramshøj (2003a), "NEG-shift in the Scandinavian Languages and English", Ms. præsenteret til Grammatik i Fokus, Universitetet i Lund, 6. februar 2003.

Christensen, Ken Ramshøj (2003b), "On the Synchronic and Diachronic Status of the Negative Adverbial ikke/not", Working Papers in Scandinavian Syntax (WPSS) 72, pp. 1-53.

Christensen, Ken Ramshøj (2004), "Negative Objects, NEG-shift, and Crosslinguistic Microvariation", Ms. præsenteret på $20^{\text {th }}$ Scandinavian Conference of Linguistics, Workshop on Syntactic Microvariation, Universitetet i Helsingfors, 8. januar 2004.

Christensen, Ken Ramshøj (2005a), "Sætningsnegation og negative objekter. Et korpusstudie", i: Widell, Peter \& Mette Kunøe (red.) 10. møde om Udforskningen af Dansk Sprog (MUDS), Nordisk Institut, Aarhus Universitet. Artiklen kan downloades her: http://www.hum.au.dk/engelsk/engkrc/papers/krc-korpus.pdf

Christensen, Ken Ramshøj (2005b), Interfaces: Negation - Syntax - Brain, Ph.d.afhandling, Aarhus Universitet. 
Christensen, Ken Ramshøj (2008a), "Interfaces, Syntactic Movement, and Neural Activation: A New Perspective on the Implementation of Language in the Brain", Journal of Neurolinguistics 21.2, pp. 73-103.

Christensen, Ken Ramshøj (2008b), "NEG-shift, Licensing, and Repair Strategies", Studia Linguistica 62.2, pp. 182-223.

Christensen, Ken Ramshøj (2009), “Negative and Affirmative Sentences Increase Activation in Different Areas in the Brain", Journal of Neurolinguistics 22, pp. $1-17$.

Christensen, Ken Ramshøj, Andreas Roepstorff, Douglas Saddy (2007), "When a Number Is Not Only a Number", poster præsenteret ved konferencen Language in Cognition, Cognition in Language, Aarhus Universitet, 11.-13. oktober 2007.

Cinque, Guglielmo (1999), Adverbs and Functional Heads. A Cross-Linguistic Perspective, Oxford: Oxford University Press.

Crystal, David (1997), The Cambridge Encyclopedia of Language, Cambridge: Cambridge University Press.

Deacon, Terrence (1997), The Symbolic Species. The Co-evolution of Language and the Human Brain, London: Penguin.

Dehaene, Stanislas (1997), The Number Sense, New York: Oxford University Press.

Diesing, Molly (1997), "Yiddish VP Order and the Typology of Object Movement in Germanic", Natural Language and Linguistic Theory 15.2, pp. 369-427.

Donald, Merlin (1991), Origins of the Modern Mind. Three Stages in the Evolution of Culture and Cognition, Cambridge, Mass.: Harvard University Press.

Fiebach, Christian J., Matthias Schlesewsky, Gabriele Lohmann, D. Yves von Cramon, Angela D. Friederici (2005), "Revisiting the Role of Broca's Area in Sentence Processing: Syntactic Integration vs. Syntactic Working Memory", Human Brain Mapping 24, pp. 79-91.

Friederici, Angela D., Christian J. Fiebach, Matthias Schlesewsky, Ina D. Bornkessel, D. Yves von Cramon (2006), "Processing Linguistic Complexity and Grammaticality in the Left Frontal Cortex", Cerebral Cortex 16, pp. 1709 1717.

Friedmann, Na'ama (2002), "The Fragile Nature of the Left Periphery: CP Deficits in Agrammatic Aphasia", i: Falk, Yehuda (ed.), Proceedings of the $18^{\text {th }}$ IATL conference, The Israeli Association for Theoretical Linguistics, The Hebrew University of Jerusalem.

Fuster, Joaquín M. (2003), Cortex and Mind. Unifying Cognition, Oxford: Oxford University Press.

Grodzinsky, Yosef (1990), Theoretical Perspectives on Language Deficits, Cambridge Mass.: MIT Press.

Grodzinsky, Yosef (2000), "The Neurology of Syntax: Language Use Without Broca's Area", Behavioral and Brain Sciences 23.1, pp. 1-71.

Grodzinsky, Yosef (2006), "A Blueprint for a Brain Map of Syntax", i: Grodzinsky, Yosef, Katrin Amunts (eds.), Broca's Region, New York: Oxford University Press. 
Haegeman, Liliane (1994), Introduction to Government and Binding Theory, $2^{\text {nd }}$ Edition, Oxford: Blackwell.

Haegeman, Liliane (1995), The Syntax of Negation, Cambridge University Press.

Hagiwara, Hiroko (1995), "The Breakdown of Functional Categories and the Economy of Derivation", Brain and Language 50, pp. 92-116.

Hanakawa, Takashi, Manabu Honda, Nobukatsu Sawamoto, Tomohisa Okada, Yoshiharu Yonekura, Hidenao Fukuyama, Hiroshi Shibasaki (2002), "The Role of Rostral Brodmann Area 6 in Mental-operation Tasks: an Integrative Neuroimaging Approach", Cerebral Cortex 12, pp. 1157-1170.

Hansen, Erik (1977), Doemonernes Port, Støttemateriale til Undervisningen i Nydansk Grammatik, København: Hans Reitzels Forlag.

Hasegawa, Mihoko, Patricia A. Carpenter, Marcel Adam Just (2002), “An fMRI Study of Bilingual Sentence Comprehension and Workload", NeuroImage 15, pp. 647-660.

Hasson, Uri, Sam Glucksberg (2006), “Does Understanding Negation Entail Affirmation? An Examination of Negated Metaphors", Journal of Pragmatics 38.7, pp. 1015-1032.

Hinzen, Wolfram (2006), Mind Design and Minimal Syntax, Oxford: Oxford University Press.

Hockett, Charles F. (1960), "The Origin of Speech", Scientific American 203, pp. 88-96.

Horn, Laurence (2001), A Natural History of Negation, Stanford: CSLI Publications.

Humphries, Colin, Tracy Love, David Swinney, Gregory Hickok (2005), "Response of Anterior Temporal Cortex to Syntactic and Prosodic Manipulations During Sentence Processing", Human Brain Mapping 26, pp. 128-138.

Jordan, Michael J. (1998), "The Power of Negation in English: Text, Context and Relevance", Journal of Pragmatics 29, pp. 705-752

Joseph, Rhawn (1996), Neuropsychiatry, Neuropsychology, Clinical Neuroscience, New York: Academic Press.

Kaup, Barbara, Jana Lüdtke, Rolf A. Zwaan (2006), "Processing Negated Sentences with Contradictory Predicates: Is a Door That Is Not Open Mentally Closed?", Journal of Pragmatics 38.7, pp. 1033-1050.

Kayne, Richard (1994), The Antisymmetry of Syntax, Cambridge Mass., MIT Press.

Larson, Richard K. (1988), "On the Double Object Construction", Linguistic Inquiry 19, pp. 335-391.

Leslie, Alan M., Rochel Gelman, C. R. Gallistel (2008), "The Generative Basis of Natural Number Concepts", Trends in Cognitive Sciences 12.6, pp. 213-218.

Lonzi, Lidia, Claudio Luzzatti (1993), "Relevance of Adverb Distribution for the Analysis of Sentence Representation in Agrammatic Patients", Brain and Language 45.3, pp. 306-317.

Mesulam, M.-Marsel (1998), "From Sensation to Cognition", Brain 121, pp. 1013-1052. 
Pinker, Steven (1994), The Language Instinct, London: Penguin.

Pinker, Steven, Paul Bloom (1990), "Natural Language and Natural Selection", Behavioral and Brain Sciences 13, pp. 707-784.

Platzack, Christer (2001), "Multiple Interfaces", i: Nikanne, Urpo, Emile van der Zee (eds.) Cognitive Interfaces. Constraints on Linking Cognitive Information (pp. 21-53), Oxford: Oxford University Press.

Pollard, Carl, Ivan A. Sag (1994), Head-driven Phrase Structure Grammar, Chicago: University of Chicago Press.

Pollock, Jean-Yves (1989) "Verb Movement, Universal Grammar, and the Structure of IP", Linguistic Inquiry 20.3, pp. 365-424.

Poole, Geoffrey (2002), Syntactic Theory, Houndsmills: Palgrave.

Radford, Andrew (2004), Minimalist Syntax. Exploring the Structure of English, Cambridge: Cambridge University Press.

Raichle, Marcus E., Ann Mary MacLeod, Abraham Z. Snyder, William J. Powers, Debra A. Gusnard, Gordon L. Shulman (2001), "A Default Mode of Brain Function", Proceedings of the National Academy of Sciences 98.2, pp. 676-682.

Rizzi, Luigi (1997), "The Fine Structure of the Left Periphery", i: Haegeman, L. (red.), Elements of Grammar, Dordrecht: Kluwer, pp. 281-337.

Thrane, Torben (2004), "Hvorfor er sproget så svært at forstå, når det er så let at forstå?", Tidsskrift for Sprogforskning 2.2, pp. 37-70.

Togeby, Ole (2003), Fungerer denne saetning? - Funktionel dansk sprogloere, Copenhagen: Gads Forlag.

Uriagereka, Juan (1998), Rhyme and Reason. An Introduction to Minimalist Syntax, Cambridge, Mass.: MIT Press.

Uriagereka, Juan (1999), "Multiple Spell-Out", i: Epstein, Samuel David, Norbert Hornstein (eds.), Working Minimalism, Cambridge, Mass.: MIT Press, pp. 25182.

Vikner, Sten (1989), "Object Shift and Double Objects in Danish", Working Papers in Scandinavian Syntax 44, pp. 141-155.

Vikner, Sten (1995), Verb Movement and Expletive Subjects in the Germanic Languages, New York: Oxford University Press.

Vikner, Sten (2004), "Nødvendigheden af en formel tilgang til sprogvidenskab", Humaniora 2, pp. 13-16. Artiklen downloades her:

http://www.hum.au.dk/engelsk/engsv/papers/vikn04-2.pdf 


\section{NOTER}

1. Der er naturligvis andre tilgange, men de har dog basale strukturelle relationer tilfælles med X-bar-modellen, såsom hierarkisk strukturerede konstituenter, f.eks. Lexical Functional Grammar (LFG, Bresnan 2001), Feltskemaanalyse (Hansen 1977, Togeby 2003) og Head-driven Phrase Structure Grammar (HPSG, Pollard/Sag 1994). Inden for den generative lingvistik er der folk der har argumenteret for at X-bar-strukturen kan afledes af mere generelle principper (se f.eks. Chomsky 1995, Kayne 1994, Uriagereka 1998).

2. En korpussøgning i Korpus 90/2000 (40 mio. ord) på VISL (http://corp.hum.sdu.dk/cqp.html) gav 426.575 eksempler med Subjekt-Verbum(finit)Objekt (SVO) mod 60.299 for OVS, altså ca. syv gange så mange. Dertil kommer at selvom SVO er mere hyppig end OVS, er der ingen vej uden om en anden ordstilling end SVO hver gang man f.eks. skal stille et spørgsmål med hvor, hvorfor, hvordan, hvornår og hvor loenge, og i nogle tilfælde med hvem og hvad (nemlig hvor de ikke er subjekt, men objekt eller adverbial); alle disse $h v$-ord passer på den understregede plads i spørgsmålet “_tror du?". Endnu en korpussøgning gav også færre eksempler hvor $h v$ ordet før det finitte verbum er subjekt (6.525), end hvor det ikke er subjekt (22.313). (Søgning udført 8. april 2008.)

3. Grodzinskys (2006, (1)) Syntacto-Topic Conjecture (STC):

A. Major syntactic operations are neurologically individuated. B. The organization of these operations in brain space is linguistically significant.

På dansk (min oversættelse): A. Centrale syntaktiske operationer er neurologisk distinkte. B. Disse operationers organisering i hjernen har lingvistisk signifikans.

4. Negative sætninger kan også konstrueres vha. et negativt subjekt, f.eks. Ingen kom til skade og Alligevel kom ingen til skade. Visse (men ikke alle) negative adverbialer kan også stå først i sætningen, f.eks. Aldrig har det voeret sjovere og Under ingen omstoedigheder kan jeg vaere med til den slags (se Christensen 2003b, 2005: kapitel 3.2).

5. Undtagen i såkaldte ekko-spørgsmål, såsom Han kom kravlende hvorhen?

6. Bastiaanse et al. (2002) hævder dog at negationen er skadet hos Broca-afasikere hvis de vel at mærke taler et sprog hvor verbalflytning og negation interagerer, som f.eks. $\mathrm{i}$ engelsk hvor der er do-insertion (Peter eats the apple men Peter does not eat the apple), eller spansk hvor der er et negativt præfiks på verbet, og på den anden side hollandsk eller norsk, der opfører sig ligesom dansk, hvor verbet flytter henover negationen (Peter spiste aeblet versus Peter spiste ikke aeblet). Ifølge Bastiaanse et al. bliver sætningsnegation (Jeg har ikke loest den bog) ofte byttet ud med konstituentnegation (Jeg har loest ikke den bog (men jeg har loest en anden)). Jeg finder dog ikke deres argumenter særligt overbevisende. For det første, som de også selv indrømmer (s. 250), kan deres tese kun redegøre for engelsk og norsk, dvs. halvdelen af deres data. For det andet er det ikke klart at deres afasipatienter rent faktisk producerer konstituentnegation. Det ser snarere ud som om problemet ligger i placeringen af verbet hvilket passer bedre med profilen generelt. 